\title{
Creativity in Teaching Different Subjects in English through Drama Techniques
}

\author{
Dr. Adriana Dervishaj
}

Lecturer at Tirana University, Faculty of Foreign Languages, English Department

\section{Doi:10.5901/jesr.2014.v4n2p438}

\author{
Dr. Rudina Xhillari
}

\begin{abstract}
This action research examines the basic concept of creativity, theoretical and practical foundations and implications of drama and theatre as a method for creative foreign language teaching, especially for teaching English as a foreign language to Albanian students at Tirana University and other district Universities. Current research has found that participation in meaningful conversations in the drama classroom helps students develop their conceptual understandings of the subject matter and further develop their creative thinking and learning. Learning outcomes and findings are often shown through descriptions of design interventions that have taken place in ordinary classrooms. In this research, attention has been paid to the use of new creative methods, diverse experiences of individual students within FL classes and what they take away from participation in such discourses.
\end{abstract}

\section{Introduction}

\section{Creativity is a basic capacity of human intelligence}

Human intelligence is not only creative, but multifaceted. It is for this reason that teachers argue that all young people have creative capacities and they all have them differently. Some of the definitions of 'creativity' are like real food to the thought.

The English word 'creativity' and its lexeme come from the Latin term creō "to create, make". The word "create" appears in English as early as the 14th century, notably in Chaucer ${ }^{[1]}$ (in The Parson's Tale ${ }^{[2]}$ ). However, its modern meaning as an act of human creation did not emerge until after the Enlightenment. ${ }^{[1]}$

According to Cambridge dictionary, creativity as a noun means:

1. the state or quality of being creative.

2. the ability to transcend traditional ideas, rules, patterns, relationships, or the like, and to create meaningful new ideas, forms, methods, interpretations, etc.; originality, progressiveness, or imagination: the need for creativity in modern industry; creativity in the performing arts.

3. the process by which one utilizes creative ability: Extensive reading stimulated his creativity.

Scholarly interest in creativity ranges widely: the mental and neurological processes associated with creative activity; the relationship between personality type and creative ability; the relationship between creativity and intelligence, learning and mental health; and ways of fostering creativity through training and technology.

In a summary of scientific research into creativity Michael Mumford suggested: "Over the course of the last decade, however, we seem to have reached a general agreement that creativity involves the production of novel, useful products" (Mumford, 2003, p. 110).[3] Beyond this general commonality, authors have diverged dramatically in their precise definitions, with Peter Meusburger claiming that over a hundred different versions can be found in the literature. ${ }^{[4]}$

Education is a vital investment in human capital for the twenty-first century. The main focus of it would be on raising standards in Universities by using drama techniques in any English teaching subject. One of the key questions to be asked are:

1. Are creative Drama in Education techniques and cultural education important to unlock the potential of every young person?

Creativity should be regarded as an urgent need to unlock the potential of every young person.

We need the creativity, enterprise and scholarship of all our people.

By creative Drama in Education is meant forms of education that develop young peoples' capacities for original 
ideas and action: by cultural education is meant forms of education that enable them to engage positively with the growing complexity and diversity of social values and ways of life. It has been argued that there are important relationships between creative Drama in Education and cultural education, and significant implications for methods of teaching and assessment.

The concept of creativity must be changed from being something that is added on to education, skills, training and management and make sure it becomes intrinsic to all of these. Independent, 3rd December 2005.

\section{Creative drama can also be defined as:}

"An improvisational, non-exhibitional, PROCESS-CENTERED form of drama in which participants are guided by a leader to imagine, enact, and reflect upon human experiences." (Davis and Behm-my emphasis.)

"Creative Drama is not primarily concerned with teaching theatre skills, although this may of course occur. The purpose of Creative Drama is to use the natural dramatic impulse to facilitate learning in an unlimited number of fields and areas. Students naturally act out their perceptions, try out roles, and play "pretend." It is the primary way young people learn about their world. Creative Drama structures this kind of activity so that students can explore topics experientially.

Aristotle said, "Tell me and I will forget. Show me and I will remember. INVOLVE me and I will understand."

Creative Drama can foster personality growth and self-esteem. It can help students learn to work together and to think creatively. It is often a classic problem-solving exercise. It builds language and communication skills better than just about any other activity in teaching English classes. It promotes empathy by letting students step into others' shoes. It can also be used as a tool to teach literally any other subject, if lessons are carefully designed. Whenever I can, I try to support the curriculum of my students in other subjects. What's wonderful about this is that since every Creative Drama lesson necessarily involves subject content of one kind or another, you can usually design a lesson around a nondramatic curricular topic without compromising the dramatic content of the lesson at all.

Creative Drama is also sometimes called "Creative Dramatics" or "Creative Play" according to Johanna Smith, Arizona State University, 1998

From Aristotle onward, philosophers have described the educational value of the human instinct of mimic play, which I believe is the driving force behind performance.

Drama is concerned with understanding, and expressing, the qualities of human experiences. Through drama, we try to give form to the feelings and perceptions that move us most as human beings: our experiences of love, grief, belonging, and isolation, and all the currents of feeling that constitute our experience of ourselves and of others. It is through the drama that young people experiment with and try to articulate their deepest feelings and their own sense of cultural identity and belonging. A balanced creative and cultural education has essential roles in the creative and cultural development of young people.

The analysis of major traditional foreign language learning theories and teaching methodologies shows many parallels and common principles with drama and theatre methods. The examination of certain linguistic, cultural, psychological, sociological, physical, and neuro-psychological aspects of language learning with regard to drama and theatre demonstrates the positive effect of the method on the creative language learning process and the development of the emotional and social development of the learner.

This research study explores practical applications of drama and theatre in the foreign language classroom. First, some basic drama techniques, such as pantomime, role-playing, improvisation, statues, etc. are examined.

These are followed by many suggestions and ideas on how these techniques could be instrumental in developing, practicing, and applying foreign language skills and foster holistic learning. (see appendix. 1)

As Kemmis and McTaggart (1988) have described, this research involves a systematic learning process in which I acted deliberately to improve my educational context and emancipate myself from institutional constraints. I hope my colleagues shall find therefore dimensions of knowledge production and action that make meeting the demands of the new curriculum possible (implementation of Bologna process).

The exercises to be used in the class were created and compiled specifically for the warm-up and language application phase which primarily benefit oral communication skills and the creation of a supportive and relaxed learning environment. Teachers can use them without any previous theatrical training.

The research activity includes participant-observation as well as interviews/ongoing discussions with my two colleagues, reflecting upon, and evaluating my teaching methodology. The action research shall become a way to create a culture of inquiry through my reflection on action with my students and collaboration with two university lecturers.

Role-playing is one of the creative techniques explored in drama classes and carefully managed with students of 
English Language at the University. When people play roles consciously, they begin to sharpen their skills of noticing and managing their own thoughts. They are both in role and also a little apart from it, and this kind of reflective thinking can be cultivated and leads to creative learning.

Reading about or even watching a drama lesson is not the same as participating in one. And similarly, participation is not the same as teaching. Teachers benefit from teaching, presenting their work, receiving feedback and also by viewing how their colleagues navigate the unpredictable waters of drama. Here the process can be analysed while peers encourage, applaud and offer additional suggestions within a supportive and non-threatening environment.

A drama classroom remains a strong venue for learning to work in role and confirming its value in the practical sense. The teacher's role is defined as: helping students to form their ideas; helping students to test their ideas; helping students to communicate their ideas; and helping them to respond to different real-life situations. Teachers can use these skills for specific learning objectives by stepping into the fictional work of the students through using drama strategies, in particular, teacher in role.

Teachers can design the structure of the lesson carefully by taking Stanislavsky's workshop as a valuable example. In doing so, the teacher may start the class by:

- Triggering previous knowledge

- Each group reads the scene to the class

- Individually each student decides on their respective character's:

1. Perception of the 'External given circumstances'.

2. Destiny (The ideal 'Super Objective'), the place and time when the character wants to be and is 'most happy'.

3. Objectives: what does the character want to achieve during the immediate scene (e.g Nora in 'A doll's house' by Ibsen)

4. Alternative objectives

5. Actions. The active verb. Physicalsing and animating the action.

6. Pace of the scene. Marking the points when the pace is changing.

7. Inner pace of the character

- Based on this individual research, students rehearse the scene once. During this rehearsal, each student will try to achieve what their characters need/want to achieve and at the same time will try to feel/understand what the other actors/characters want.

- Individually each student will review and reassess her/his initial decisions and adjust them if necessary, according to the results of the first rehearsal.

- Second rehearsal.

- Second individual evaluation and adjustment. next class.

As an assignment students rehearse the scene, adding each others' point of view and get ready to perform it in the

The teacher may gradually move from a traditionally empirical style of teaching to a new synthesis, which is dominated by a more democratic and critical theoretical perspective. I invited my students and colleagues to participate in a Live Drama class and negotiated with them about the process at every stage in the procedure. In doing so, the students have displayed an impressive energy and enthusiasm. Even my colleagues highly estimated the students' performance.

'It is good to watch and understand a play as a two way means of communication.' - B.H (personal comments)

It was considered as 'A thoughtful and passionate performance that fuels the fires of the longstanding process/product debate close to the heart of all drama/theatre practitioners and scholars.'

Validation of findings and Important conclusions

Students discussed and drew conclusions in the end useful to their own creative learning: Keep your decisions to yourself.

Make sure the creation of the character is entirely yours. You will act it therefore you are responsible for its actions.

Lessons learned from the students' workshop:

- Emotion is a psychophysical response to events. In a drama class emotion will spring from the concentration in the given circumstances and the magic IF

- MPA - The Method of Physical Action is a set of techniques and acting exercises originated by Stanislavsky to help the student achieve wholeness in creating a character. Conscious - Subconscious - Unconscious 
- Playing games as a means of introducing the system

- The need to view Stanislavsky's system as a live adaptable technique that can be used in classroom drama situations

- The similarities between the actor's creative mood and the students in play

- The purpose of the system is to help the student to empathize with the character and consequently for the spectator to empathize with the character

- Empathy generates on involuntary physical response, beyond an intellectual or emotional one.

- The 'Here and Now' of the theatrical situation 'Not me, Not here, Not Now' simultaneously with 'Me Here Now'

- 'The Given Circumstance'; 'The Magic IF'; 'The Physical Action'; 'The Sense and Emotional Recall'; 'Tempo Rhythm of the character'; 'External adjustment'; The 'Character' is a system of movements

- Imagination - As IF - Endowment

Consistently, there is proof of unprecedented improvement in students' writing and speaking skills as a result of the use of drama structures. In the course of my practicum work, I have become a field researcher in my own classrooms, where students can speak with authority (and offer hard data) about what really works for student learning. It is more essential than ever for teachers to take up the role of being researchers, not only for evaluative purposes but so as to expand and explore the complex learning available in the aesthetic moment.

Calling us to focus on "knowing-in-action" Taylor (2000) draws our attention to drama teaching as an artistic process of meaning-making. He proposes that "to ignore reflective practitioner design is to remain ignorant to the kind of artistic processes which are the lifeblood of our work". (p. 27).

Returning to the question of value, drama, perhaps more pointedly than in any other subject area,

can not hide that, as a subject discipline and teaching methodology, it is not merely value-laden but valuesaturated.

Heathcote once again focuses the role of drama in education. "She (Heathcote) sees drama as the means of rooting all the school curriculum back in a human context where it sprang from, so that knowledge is not an abstract, isolated subject-based discipline, but is based in human action, interaction, commitment and responsibility" (Bolton, 1998:177).

\section{Conclusion}

Drama provides myriad ways for students to learn and appreciate language in meaningful, communicative contexts.

Integrated skills can be acquired during drama classes. The various language skills should not be taught separately, for it is rare that we as language users only employ grammar or only speaking or only writing.

Drama is an ideal way to bring the skills of grammar, reading, writing, speaking, listening and pronunciation together in a course where the focus is not on form but rather fluency and meaning for the following main conclusive reasons:

- Drama is used primarily to discover meaning and to come to understandings; it is the vehicle for the learning. Often the drama is serving learning from another area of the curriculum.

- The relation between student and teacher is collaborative.

- The students and the teacher are involved in an enterprise where the children are endowed with power and expertise to enable them shape and develop the work of the enterprise. The work involves making decisions and solving problems, often on behalf of someone else.

- The students are given a role within the drama related to the enterprise. The role gives a point of view or stance from which the class will approach the work. The role also gives them the power to express that point of view. With this in mind, the students don't enact a character in the conventional sense.

- The students' role gives them status and expertise not normally accredited or expected of children.

- Because the work is collaborative, the teacher has a role in the drama and 'teaches' from within the drama. Like the role for the class, the teacher's role is carefully selected to enable the work to progress, and to deepen the experience for the children.

- Teaching in this way involves interplay between the cognitive and the affective,

- Involves moving from the universal to the particular and back to the universal.

Creativity can be taught. Especially Drama Teachers can be creative in their own teaching; they can also promote the creative abilities of their students. The roles of Lecturers and Professors are to recognise students' creative capacities; 
and to provide the particular conditions in which they can be realised. Developing creativity involves, amongst other things, deepening young people's cultural knowledge and understanding. This is essential both in itself and to promote forms of education which are inclusive and sensitive to cultural diversity and change.

In conclusion, creative and cultural education is not subjects in the curriculum: they are general functions of education. They can and should be promoted in all areas of the curriculum and not just through so called creative subjects. Different areas of the curriculum do contribute to creative and cultural education in different ways. The opportunities and the focus in the arts, for example, are not identical with those of the sciences and humanities, or with physical education. Each of these broad areas contributes in different ways to a balanced education.

\section{Reference}

Andersen, Christopher, Learning in "As-If" Worlds: Cognition in Drama in Education Theory Into Practice - Volume 43, Number 4, Autumn 2004, pp. 281-286.

Baldwin, P. 2004. With Drama in Mind: real learning in imagined worlds. Norfolk: Network Press.

Bell, G.H. (1998) "Arts Education and the European Dimension" in Bloomfield, A. (ed.)

The Artistic Experience, Aspects of Education No. 55, University of Hull

BERA Music Education Review Group (2001) Mapping Music Education in the UK

BERA (PDF from website) www.bera.ac.uk/publications/acreviews.php : British Educational Research Association

Booth, D. 1994. Story Drama: Reading, writing and roleplaying across the curriculum. Toronto:

Pembroke Publishers Limited.

Bruner, J. (1990). Acts of Meaning. Massachusetts: Harvard University Press.

Coutts, G. (2003) Art and Design Education. In T. Bryce and W. Humes (Eds) Scottish

Education, 2nd Edition: Post-Devolution. Edinburgh: Edinburgh University Press.

Fiske, E.B. (1999) Champions of Change: the Impact of the Arts on Learning, Chicago:

The Arts Education Partnership

Freire, P. 1998. Pedagogy of Freedom: Ethics, Democracy, and Civic Courage. Lanham, Maryland: Rowman and Littlefield Publishers, Inc.

Gallagher, K. 1998. Girls, Experience, and Voice in D. Booth and J. Neelands (eds.) Writing in Role: Classroom Projects Connecting Writing and Drama. Hamilton, ON: Caliburn Enterprises Inc. pp141-154.

Gallagher, K.2001. Drama Education in the Lives of Girls. Toronto: University of Toronto Press.

Galt, V. 2000 March 8. Boys far outrank girls in behaviour, learning problems: Statscan. In Toronto Globe and Mail. p. A3).

Greene, M.1995. Releasing the Imagination: Essays on Education, the Arts and Social Change. San Francisco: Jossey-Bass.

Greene, M. 1996. Forward in P. Taylor (ed.) Researching Drama and Arts Education: Paradigms and Possibilities. London: Falmer Press.

Grundy, S. 1998. Research Partnerships: principles and possibilities in B. Atweh, S. Kemmis and P. Weeks (eds.) Action Research in Practice: Partnerships for Social Justice in Education. London and New York: Routledge. pp. 37-46. 